\title{
Kinesin Light Chain 1
}

National Cancer Institute

\section{Source}

National Cancer Institute. Kinesin Light Chain 1. NCI Thesaurus. Code C106345.

Kinesin light chain 1 ( $573 \mathrm{aa}, \sim 65 \mathrm{kDa}$ ) is encoded by the human KLC1 gene. This protein plays a role in microtubule motor activity. 